\title{
Round Table Model: A Cooperative Learning for Engineering Education
}

\author{
Bakhrani Rauf ${ }^{\mathrm{a}, 1}$, Ayuddin ${ }^{\mathrm{b}, 2}$ \\ ${ }^{a}$ Engineering Faculty, Makassar State University, Makassar, INDONESIA \\ ${ }^{\mathrm{b}}$ Civil Engineering Department, Gorontalo State University, Gorontalo, INDONESIA \\ 1bakhranirauf192@yahoo.com, 2ayuddin_ung@rocketmail.com
}

\begin{abstract}
The subjects in this research is the Construction Building for PTB departement on UNG. The author concluded that most of the learning activity has a low presence, the same problem also occur in the students assigned tasks. This is due to a lack of enthusiasm, participation, and activeness of students. Therefore, we need an effort to overcome the problem of learning strategies which can improve student learning outcome. The Learning strategies applied in this study is a model of the Round Table. This study is a classroom action research that aims to improve learning result of students in the PTB department of Gorontalo State University through Round Table model. The Subjects are 17 students in the second semester. This study was conducted in two cycles. From the analysis it concluded that the results of the students outcome on the second semester in PTB departement at the subjects of Building Construction increased from cycle I to cycle II, after conducted Round Table model. The results of the qualitative analysis showed good progress in the attitude of students and student interest during the learning process.

Index Terms - round table model, engineering education, learning result
\end{abstract}

\section{Introduction}

The quality of education in Indonesia still become unresolved problem and continues to be developed by education experts. We observe that many lecturer as spearheading a success in the teaching process still use the old method to find the material that will be presented to the student. The material also made based on the syllabus which does not consider the interactions process to make students understand better. Lecturers still use the conventional method without considering the mental development of students, so the knowledge is easily forgotten. There are still found lecturers who teach without consider new model or learning pattern that made good atmosphere in the classroom. In the learning and teaching process, students are expected to acquire the ability to manipulating social issues, ask and answer questions, propose to solve the problem, examine the various social phenomena and so on. So the students really involve in the learning process. Another phenomenon that also found is the lecturers provide much knowledge and it's only focused with student activity without regard to the essence of quality. It is rarely found the lecturers have good preparation and proper methodology in teaching. So we need to make a model or pattern that can make better condition in the classroom.
After the learning process we expect the student can acquire the ability to try and examine more deeply about the material being taught, including asking questions, answering questions, and solving problems, so that students have an involvement in the learning process.

The criticism also is the habit of lecturers to take a shortcut and easiest way to mastery a curriculum targets, regardless of the level of mastery of educational goals in particular, so it is necessary to develop a learning strategy in engaging students both physically and mentally for acquisition process and make it possible to achieve a more adequate educational purposes.

This contrasts with the educational goals that the purpose of education is not only transfer the knowledge and skills to children, but more important is to create opportunities and allow the child to be able to hold its own investigations and discoveries. The emphasis in the teaching and learning process should be shown to the acquisition of learning outcomes. The concept of teaching which is conducted by lecturers is expected to interact actively with students, also the teaching material can be mastered and fully understood by the students. So, the better learning atmosphere can be achieved. As educational expectations that are intended to improve the ability of students, both in cognitive, affective, and psychomotor.

Observing the phenomenon of this model, the authors took the initiative to develop a model that has a creative and innovative ideas in teaching and learning to be applied to the PTB particular majors at the State University of Gorontalo. The model is a Round Table. Round Table is one type of cooperative learning models that form small groups which is arranged with circular formation. This model aims to teach a process or procedure that must be mastered by the student, to make the information or explanation become real for the students, and develop observational skills to study together. The concept of this model oriented to make student learning process and the quality of students is more promising, because the proper teaching methodology can be decisive in improving the quality of a students. Hopefully this model can be useful 
and become inputs to improve the quality of technology education in Indonesia.

\section{Theoretical Foundation}

A. Definition of Learning

According to Burns (1995, p 99) that learning conceiving as a relatively permanent change in behaviour including both observable activity and internal processes such as thinking, attitudes and emotions. It is clear that Burns includes motivation in this definition of learning. Burns considers that learning might not manifest itself in observable behaviour after several period.

Thus, learning is a design, pattern or design that is used to guide learning process in the classroom. This is aims to create a conducive atmosphere to make the students feel free to respond naturally and regularly. So the learning objectives achieved well. So learning is the process where the environment is managed deliberately to allow the persons participate in a particular behavior, so that the special conditions will result in the response to certain situations as well. Orientation of learning is to make people want to change their mind from incapable to be capable. The goal of learning is to get knowledge; developed the concept; understand the analytical techniques, develop themselves in such skills in analyzing problem-solving skills, skill in synthesizing activity and implementation, as well as skills in communication.

\section{B. Definition of Round Table Learning}

According to Lacy in http://www.wikipedia.com said that the round table was first introduced by Arthur King of England. Round table was made to resolve disputes between sugar farmers. The round table is also used to discuss problems that arise in the internal and external empire for example in determining the strategy or tactics of war. The position of the soldier at the time was a circular that surrounds the king.

Therefore, from this development can be considered that the teaching and learning activities in small groups where the table drawn with circular models. The questions is given by the lecturers and to be answered by each groups that have been established previously. With this understanding, the round table is in the category of cooperative learning for applying the learning to appoint each member of the group take turns to participate in the group and they sit in a circle table.

\section{Method}

This research is a Classroom Action Research which is aims to improve learning outcomes of Building Construction through the Round Table learning model at the students of second semester PTB at the State University of Gorontalo. The procedure of this study is conducted in two cycles, each cycle consisting of four stages, namely; planning, implementation, observation, and reflection.
The activities in planning steps is to prepare lesson plans, develop evaluation tools in the form of subjective tests, and form study groups with Round Table model. The all phases of learning process in the classroom should be done including the presentation of the learning objectives and motivated the student, and deliver material according to the lesson plan and the end of each cycle, providing teaching evaluations to students on an individual basis in the form of an essay test to determine how is the increasing level of the student learning outcomes if the process of teaching and learning using round table model. In the next stage is the observation stage, this stage implement the action by using the observation sheet about the presence and activity of students, as well as carrying out an evaluation at the end of the cycle to determine student learning outcomes obtained in cycle I. Meanwhile, the reflection phase is aims to reflect student learning progress from the data which collected from observations and evaluation results whether the activities carried out an effect on student learning outcomes in study subjects Building Construction. The results of the data analysis in this stage will be used as a reference to plan the next cycle. So also performed on the second cycle. Chart design of this study can be seen in Figure 1 below.

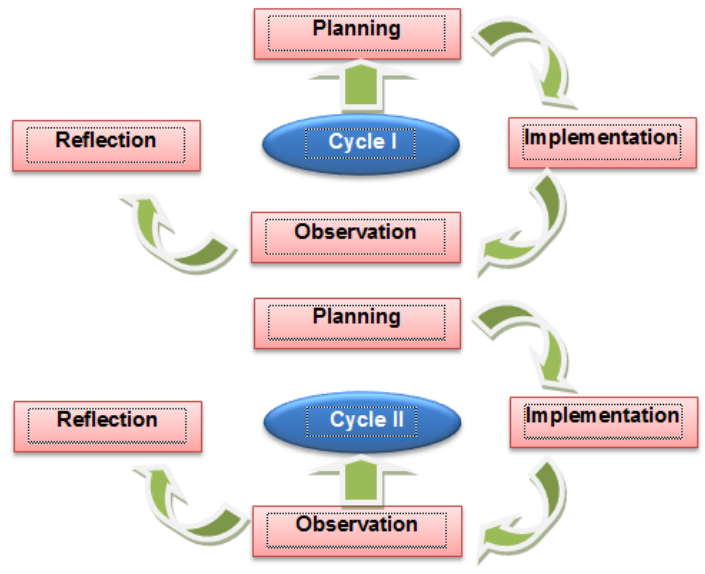

Fig. 1. Research design

The design of data analysis using descriptive statistical analysis of quantitative average and percentage. In addition, the table also determined the frequency and percentage of the value of the minimum and maximum values obtained by students in each cycle.

\section{Result and Discussion}

In the learning process in the first cycle the action performed on three activities, namely: (1) initial activities include ensure all students present in class to learn and the teachers explain the learning method and deliver the learning material in a round table learning model, (2) the core activities : Doing exploration and explanation of the material to the 
students, provide questions to a group of students who previously formed, establish detailed discussion between lecturer and the group of students at the round table and discussion among other groups, draw conclusions from the results generated discussion. At the core of this implementation is also carried out an effort to increase students' motivation by giving an award to the student who gave the best answer and directed as praise and value added thus also motivate other students to be more active next meeting, (3) the activity: In the final stage, the students are asked to give an opinion about the round table models and provide reinforcement of the importance of these lessons and give information about the material that will be discussed next meeting.

Description of the observation of the activity of the students during the learning process takes place is shown in Table 1 below.

TABLE I. STUDENT ACTIVITY DURING LEARNING HELD IN CYCLE I

\begin{tabular}{|c|c|c|c|c|c|c|}
\hline \multirow{2}{*}{ No } & \multirow{2}{*}{$\begin{array}{l}\text { Student Activities } \\
\text { During of BBM }\end{array}$} & & \multicolumn{2}{|c|}{ Meeting } & \multirow{2}{*}{ Average } & \multirow{2}{*}{$\begin{array}{c}\text { Percentage } \\
(\%)\end{array}$} \\
\hline & & & 1 & II & & \\
\hline 1 & $\begin{array}{l}\text { The number of } \\
\text { students in attendance } \\
\text { at the time of learning } \\
\text { activities }\end{array}$ & \multirow{6}{*}{$\begin{array}{l}\text { C } \\
\text { y } \\
\text { c } \\
\text { I } \\
\text { e } \\
\text { I }\end{array}$} & 15 & 16 & 15.5 & 91.18 \\
\hline 2 & $\begin{array}{l}\text { Listening to the } \\
\text { explanation of lecturer }\end{array}$ & & 10 & 15 & 12.5 & 73.53 \\
\hline 3 & $\begin{array}{l}\text { Students who do } \\
\text { negative activity } \\
\text { during the learning } \\
\text { process }\end{array}$ & & 2 & 1 & 2 & 8.82 \\
\hline 4 & $\begin{array}{l}\text { Students who are } \\
\text { active in the learning }\end{array}$ & & 15 & 16 & 15.5 & 91.18 \\
\hline 5 & $\begin{array}{l}\text { Students who present } \\
\text { a discussion and talk } \\
\text { right in front of the } \\
\text { class }\end{array}$ & & 2 & 3 & 2.5 & 14.71 \\
\hline 6 & $\begin{array}{l}\text { Ask a response, } \\
\text { denying and give } \\
\text { another answer with } \\
\text { their reasons }\end{array}$ & & 3 & 6 & 4.5 & 26.47 \\
\hline 7 & $\begin{array}{l}\text { students who still need } \\
\text { the guidance of } \\
\text { lecturer }\end{array}$ & & 12 & 7 & 9.5 & 41.18 \\
\hline
\end{tabular}

Source: Results of analysis

Based on the analysis of student activity during the learning process in the first cycle it seen that the students who attended the first meeting are 15 students and 16 students in the second meeting from 17 student as a whole. So the average percentage of students who were present at the time of learning in the first cycle was $91.18 \%$. Students listening to the explanation lecturer at the first meeting are 10 students and 15 students in the second meeting from 17 student as a whole so the average percentage is $73.53 \%$ of the 17 number of students. Students who do negative activity during the learning process at the first meeting are 2 students and 1 student in the second meeting from 17 student as a whole, so the average percentage is $8.82 \%$ of the 17 number of students. For students who are active in the learning at the first meeting of are 15 students and 16 students in the second meeting from 17 student as a whole, so the average percentage is $91.18 \%$ of the total number of students. Students who present a discussion and talk right in front of the class at the first meeting are 2 students and at the second meeting are 3 students from 17 total number of students, so the average percentage is $14.71 \%$ of the total number of students 17 . For students who submit a response to the first meeting and are 3 students in the second meeting are 6 students from 17 the number of students, so the average percentage is $26.47 \%$ of the total number of students 17 . While students who still need the guidance of a lecturer at the first meeting are 12 students and 7 students in the second meeting from 17 total number of students, so the average percentage is 41.18 percent of the total number of students 17 .

From the observations at the beginning of the cycle, then the next test results of the evaluation of learning outcomes in the Building Construction subjects given to students of PTB at the second meeting of the first cycle were obtained from the following table of descriptive statistic. Description can be seen in Table 2 below.

TABLE II. PERCENTAGE SCORE OF LEARNING OUTCOMES TO BUILDING CONSTRUCTION SUBJECTS IN THE FIRST CYCLE

\begin{tabular}{|c|c|c|c|}
\hline Value Interval & Ctegory & Frequency & Percentage (\%) \\
\hline $0-34$ & Very Low & 0 & 0 \\
\hline $35-54$ & Low & 2 & 11.76 \\
\hline $55-64$ & Medium & 4 & 23.53 \\
\hline $65-84$ & High & 9 & 52.94 \\
\hline $85-100$ & Very High & 2 & 11.76 \\
\hline \multicolumn{2}{|c|}{ Number } & 17 & 100 \\
\hline
\end{tabular}

Source: Results of analysis

In Table 2 indicate that the PTB of mastery learning students in the first cycle is not fully maximized. It is seen that the students who scored in the low category are 2 students with a percentage of $11.76 \%$, students who are in the category are 4 students with a percentage of 23:53\%, students who are in the high category 9 students with the percentage of 52.94\%, a student who is at very high category are 2 students with persentse $11.76 \%$, in the first cycle of this study also showed that only 2 students who have a very high score. The data results of this study become one of reflection for full implementation of the second cycle. From the data in the first cycle of learning outcomes which indicate that the learning outcomes of students in the category Building Construction is low, then should be improvement in the next cycle. Here are shown in Figure 1 of the results of learning cycle I.

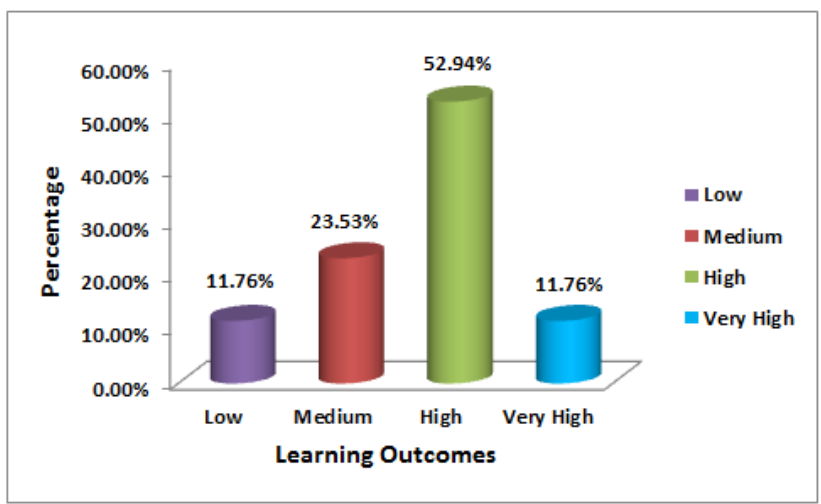


Fig. 2. The value of learning outcomes for building construction in the first cycle

In the implementation of the first cycle shows the lack of student interest in the learning process. Therefore, further efforts should be made to make improvements. However, at the end of this cycle the student interaction on the learning process with Round Table model show a positive change, it is seen from the reflection the students start to have motivation in learning, and the activities from Round Table learning model perceive them to train themselves to be independent in solving problems. In addition, also the students can be independent in completing a given task without having to rely on the lecturer as a source of information. The results of these reflections are the basis for the continuation of the implementation of the second cycle of action by seeking improvement through Round Table learning, also motivated the students to use course materials that have been read to solve the problems that exist, make summary answer to the question that has been asked, emphasizing to students for make a small note about the questions they ask.

In the second cycle, the learning process has good progress, it is seen by the number of students who get very high score is higher than the previous cycle. From the 17 students who took the test in the second cycle, learning outcomes of students in the high category are 12 people whereas before the beginning of the cycle only 9 people with the percentage of $70.59 \%$ and 5 students at the high category with a percentage of $29.41 \%$. It was observed also in this second cycle is the level of student learning independence is quite well, where the previous session still a lot of students who rely on other friends which causes them not to believe in themselves, and they prefer to imitate their friend's summary to complete the task. But in this cycle is the average student prefers doing their job by themselves so that they are more easily mastered and does not experience difficulty when they are given tests or replications. These data reinforce previous data, namely an increase in the number of students who are able to work on a given task. In this second cycle increasing both the activity, attendance, and student learning outcomes. This progress occurred after the repairs are considered not performing optimally on the previous cycle. From this description it can be concluded that the implementation of the learning process of a round table on the second cycle is running better than before. It shows the change in the attitude of students from the first cycle to the second cycle always leads to the things that have been planned in accordance with the steps that have been prepared on the research procedure. The increase in the first cycle to the second cycle of learning outcomes can be seen in figure 3 below.

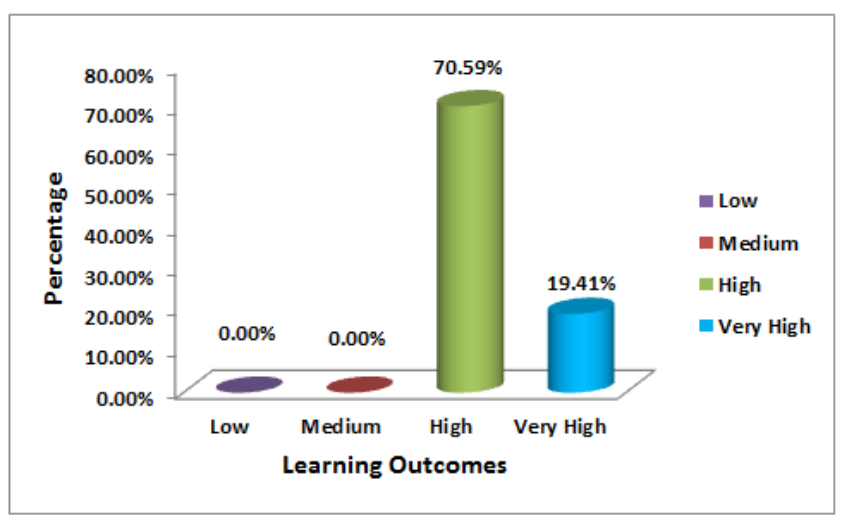

Fig. 3. The value of learning outcomes for Building

Construction in the second cycle

Based on observations in the implementation of the second cycle indicates that the enthusiastic students who attend classes, they even happy in the application of round table model because they can understand the material better and more deeply. The student enthusiasm can be seen in the frequency of the presence of student motivation during the learning process in the implementation of the second cycle and the ability of students to understand the material increased. Improved learning outcomes from the first cycle to the second cycle can be seen in Table 3 below:

TABLE III. PERCENTAGE SCORE OF LEARNING OUTCOMES TO BUILDING CONSTRUCTION AT THE INITIAL TEST AND AFTER THE LEARNING PROCESS IN CYCLE I AND I

\begin{tabular}{|c|c|l|c|c|c|c|}
\hline \multirow{2}{*}{ No } & \multirow{2}{*}{$\begin{array}{c}\text { Score } \\
\text { Interval }\end{array}$} & \multirow{2}{*}{ Category } & \multicolumn{2}{|c|}{ Frequency } & \multicolumn{2}{c|}{ Percentage (\%) } \\
\cline { 4 - 7 } & & Cycle I & Cycle II & Cycle I & Cycle II \\
\hline 1 & $0-34$ & Very Low & - & - & - & - \\
\hline 2 & $35-54$ & Low & 2 & - & 11.76 & - \\
\hline 3 & $65-64$ & Medium & 4 & - & 23.53 & - \\
\hline 4 & $65-84$ & High & 9 & 12 & 52.94 & 70.59 \\
\hline 5 & $85-100$ & Very High & 2 & 5 & 11.76 & 29.41 \\
\hline \multicolumn{3}{|c|}{ Number } & 17 & 17 & 100 & 100 \\
\hline
\end{tabular}

In the implementation of this second cycle so many changes in addition to an increase in learning outcomes Building Construction. The changes that occur in the first cycle is the percentage of student attendance on the first cycle of $91.18 \%$ increased by $97.06 \%$ in the second cycle. In the first cycle in terms of listening to the explanation lecturer at $73.53 \%$ increased by $85.29 \%$ in the second cycle. The percentage of students who perform negative activity decreased during the learning process of the first cycle of 8.82 becomes $2.94 \%$ in the second cycle. In terms of the activity also increased from the first cycle of $91.18 \%$ to $97.06 \%$ in the second cycle. When seen the ability of students who present discussion material also increased from the first cycle of $14.71 \%$ to $55.88 \%$ in the second cycle. So also when observing the student in terms of his own reason to submit a response to the rise of the first cycle of $26.47 \%$ to $67.65 \%$ in 
the second cycle. From students who need guidance has decreased from $41.18 \%$ to $17.65 \%$ first cycle to the second cycle. This shows that learning on the second cycle had a significant increase in all the side from the previous cycle. Thus, the round table learning method is very successful applied to the PTB subjects in Civil Engineering Department, State University of Gorontalo. Here are shown in figure 4 Building Construction learning outcomes in the first cycle and the second cycle.

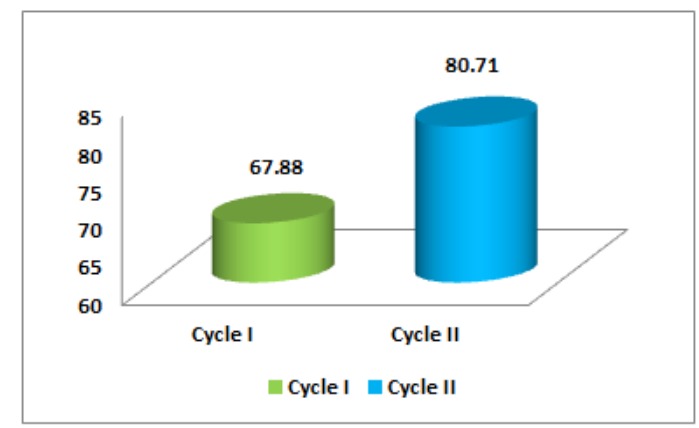

Fig. 4. Results of Building Construction learning for cycle I and II

The increase occurred both attendance and learning outcomes of students in the second cycle. It occurs after improvement were considered not to performing optimally on the previous cycle on the results of observations obtained during the learning process takes place. The improvements that could happen is if the first cycle degree students only above average intelligence who are active in the learning process, the second cycle to approach students are below the level of intelligence of the average to get direct guidance so that they are more active and can involve themselves in the learning process according to the model of applied learning. It can be concluded that the second cycle of the round table on the implementation of learning goes better than the previous cycle.

\section{Conclusions}

From various considerations and empirical evidence show that the learning model is most appropriate round table in the PTB departement in improving student learning outcomes. Based on the test results of the application of the round tables Learning Model from cycle I to cycle II was increased. This is shown in the category of learning outcomes PTB cycle I gained an average score of 67.88 at the high category level of mastery learning with 11 students, while the student learning outcomes of PTB in cycle obtaining an average score of 80.71 that the category with the high level of mastery learning are 17 students. So it can be concluded that the learning round table has an advantage in the application include a) the attainment of higher academic learning outcomes; b) is more conducive to improving relationships between students and lecturers c) increase the attention and activity of students in the learning process.

\section{Acknowledgment}

The author would like to thank for department of civil engineering, faculty of Engineering, Gorontalo State University for conducting the research. Lastly, the author would also like to thanks the UPI International Conference on TVET for this publication.

\section{References}

[1] Albert, Charles E. \& McCartney, Catherine E, "Study Guide for Slavin Educational Psychology Theory and Practice". Fifth Edition. Boston: allyn ang Bacon, 1997.

[2] Arends, Richard I, "Classroom Intruction and Management", Mc GrawHill, 1997.

[3] B.G. Wilson, "Constructivist Learning Environments: Case Studies in Instructional Design". Educational Technology Publications, Englewood Cliffs, NJ, 1996.

[4] Bransford, J. A. D., Brown, L. \& Cocking, R.R, "How people learn: Brain, mind, experience, and school". Washington, DC: National Academy Press, 1999.

[5] Burns, R, "The adult learner at work". Sydney: Business and Professional Publishing, 1995.

[6] Elias, J. L., \& Merriam, S. B, "Philosophical foundations of adult education". Malabar, FL: Krieger Publishing Company, 1995.

[7] Hill, Susan \& Hill, Tim, "The A Guide to Co-operative Learning, Collaborative Classroom". Printed by SRM Production Sevice Sdn.Bhd. Malaysia, 1993.

[8] Johnson, DW,\& Johnson,R, "Cooperative and Competion: Theoru and Research”. Edina,MN: Interaction Book Company, 1989.

[9] Lacy, Norries J, "Round Table". Dalam http://www.wikipedia.com. Diakses pada tanggal 2 Pebruari 2014, 1991.

[10] M.D. Merrill, "Instructional Design Theory, Educational Technology Publications". Englewood Cliffs, NJ, 1994.

[11] Medsker, Karen L, dan Holdsworth, Kristina M, "Models and Strategies for Training Design". About ISPI. Printed in United states of Amirica, 2001.

[12] Mezirow, J, "Transformative dimension of adult learning". San Francisco: Jossey-Bass. Fraenkel, J., 1993. How to design and evaluate research in education. Mcgraw, S.1, 1991.

[13] Pintrich, P. \& Schunk, D, "Motivation in education: theory, research, and applications". Englewood Cliffs, NJ: Prentice Hall, 1996.

[14] Sharan, Yael \& Shlomo Sharan, "Expanding Cooperative Learning Throuhg Group Investigation", New York: Teachers Collage Press, 1992.

[15] Slavin, Robert E, "Cooperative Learning". Printed in United states of Amirica, 1995.

[16] Slavin, R.E, "Educational Psychology Theory and Practice". Fifth Edition. Masschussets: Allyn and Bacon Publiser, 1997. 